\title{
ESL Teachers' Perceptions towards the Use of Facebook in Teaching Literature for Secondary Schools
}

\author{
Logenthini Mariappan \\ Abdul Ghani Abu \\ Ainon Omar \\ Faculty of Languages and Communication \\ Universiti Pendidikan Sultan Idris (UPSI) \\ Tanjong Malim, Perak \\ Malaysia
}

Email:logen1702@gmail.com

\begin{abstract}
School-based print texts and didactic teaching appear slow and unexciting, thus there is a need to integrate social networking sites in the teaching and learning process. Facebook is one of the social networking sites that has captured the attention of educators in language teaching and learning. The use of Facebook in teaching Literature is beneficial and gives teachers the chance to improve teaching via a lively classroom. This study surveyed the perceptions of secondary school teachers on the use of Facebook in teaching literature. A 30-item questionnaire was administered to 100 secondary school teachers in Malaysia. The teachers from 10 states were involved in this study and they are currently teaching English language in secondary schools in Malaysia. The findings indicated that teachers found Facebook as the most useful aspect of Internet in teaching literature and they prefer to use Facebook as a teaching tool compared to the classroom blackboard. This study recommends the use of Facebook as a Literature teaching tool in secondary schools.
\end{abstract}

Keywords: Facebook, Teaching, Literature, Perception, Social Networking Sites

\section{INTRODUCTION}

The usage of social networking sites has developed rapidly during a last decade and the usage has been spread to almost all aspects of life including education by playing a major role in the development and innovation of teaching styles. As we all know social networking sites have changed the lives of human beings dramatically and these have been abundant in the everyday lives of people. While teachers were using chalk and talk only in the classroom until recently, now, they are using social networking sites for almost every lesson instead of traditional teaching methods. With the advent of sophisticated tools, social networking sites have almost replaced the traditional teaching methods used in the classroom. 
Although the authorities, teachers and students have different views toward the usage of social networking sites, educators cannot ignore the important role played by social networking sites such as Facebook (Siegle, 2011). This is one of the reasons the educators have begun to incorporate social networks into the teaching and learning process. In addition to that, in a study conducted by Mazer, Murphy, and Simonds (2009), they found that teachers may enhance their reliability if they use Facebook, showing they care about their students and understand existing students' interests. Students often respect teachers who use instructional strategies that value what they value.

According to Sidhu (2003), studies have reported that students were seen to be passive and literature lessons were often too teacher-centred and due to that, teachers are labeled to be dull and less creative. These situations specify that teachers need different strategies and tools to teach and capture learners' imaginations to adequate their thought patterns and new socialization habits (Godwin-Jones, 2008). During the last decade, the number of students and educators becoming active members of SNSs especially Facebook has increased. As there are 93\% of young people ages 12-17 who go online and $73 \%$ of them frequently visit social networking sites (Lenhart et al., 2010), it is not surprising that teachers are using social networking sites especially Facebook in academia.

Although the main function of Facebook is not for educational use, there are a few efforts to enhance its use in the teaching of English literature. Most researches on the educational use of Facebook focuses only on its impact on motivation and ideas for using Facebook. However, only a few studies have been done to explore teachers' perceptions, especially in a secondary context. In fact, secondary English teachers' perceptions are of paramount importance as they affect their practice and students' learning experience.

To address this gap, this study explored the perceptions of 100 secondary school teachers towards the use of Facebook in English Literature, the current use of Facebook in class, and possible challenges teachers may face. In order to facilitate the investigation regarding the perceptions towards the use of Facebook in teaching Literature, the researchers form the following research questions:

a) What are the perceptions of the teachers in incorporating Facebook in teaching of Literature?

b) How does Facebook help in improving teaching of literature in the secondary school?

The aim of carrying out this research is to examine if the usage of Facebook in teaching can help ESL teachers and students with their teaching and learning of Literature. In addition to that, the aim of the research is also to find out the benefits of using Facebook in teaching literature. Moreover, it is assumed that the findings from this study will encourage the use of Facebook in teaching Literature and improve literature teaching in ESL classrooms. The participants in this study are school teachers from 10 states in Malaysia. 


\section{LITERATURE REVIEW}

A few decades ago, the traditional method was the best way of teaching at schools but nowadays it is commonly believed that, students just need to use social networking sites in learning. As we all know, social networking sites have become the most important platform that connect them to learning process in today's trend. According to Noyes (2015), of all the social networking sites, Facebook is considered as the most widely used social networking sites due to its continually increasing active members and due to this it can be a favorable educational tool as well.

Facebook is a tool used to interact and connect with contacts that the user knows such as family and friends (Ellison, Steinfield, \& Lampe, 2007). As we all know Facebook is one of the most popular social networking sites and has been widely used by students (Johnston, 2013).The motives of using Facebook are to maintain existing relationship with people and find out information about people whom we met before. In addition to that, the motives of Facebook are to raise awareness of oneself, ability to express oneself by updating their profiles, communicate with one another for learning purposes and finally enabling students' activism (Hew, 2011).

Kho and Chuah (2012) conducted a study on the usage of Facebook and they recommended educators to incorporate Facebook in teaching and learning activities to create more fun and interactive lessons. In addition to that, Northcote, and Kendle (2001) suggest that participating in online learning activities will provide students the opportunity to obtain practical skills such as critical analysis of resources, effective online communication, and filtering and interpreting information in a more informal manner.

It can be said that Facebook groups allow people to share information and bring a valuable functionality to the classroom. Facebook groups can be used to communicate relevant course and material. The user in turn can view the posted material and comment on it or they can even make their own posting. This involved posting information regarding subjects, such as syllabi, lesson lists, exam reviews and study materials. Instructors will also be able to create calendar reminders for classified events, which automatically populated the students' Facebook calendar and appeared in their Newsfeed.

On the other hand, Fodeman \& Monroe (2009) state that Facebook use will lead to wasting of time or overspending of time. In addition to that, Facebook encourages negative attitudes such as lying and it affects students' social growth as well. Due to this mixed impact of FB, there is an ongoing debate among researchers and academics as to whether FB should be taken seriously as a learning tool.

In contrast to the above argument, Roth (2009) suggests that technology should be made a significant component in the curriculum and by adapting technology, the teaching and learning process will be more interactive and holistic. The students can also move away from being passive towards active learning. Chang, Chen, and $\mathrm{Li}$ (2008) state that compared to traditional classroom, web-based classroom can improve students' coursework features and advance their learning performance. It can be said that, online discussion forums provide the opportunity for the students to collaborate, 
share knowledge without meeting the person or to work simultaneously ( $\mathrm{Li}$ and Chen, 2009).

As we all know, Facebook is a more advanced online interactive site and it shares the major features such as online discussion. Individuals can access online freely to share information and communicate with others either directly or indirectly. Online based interaction can also help those shy students to voice out in the class or be involved in discussion activities (Chang, Chen, \& Hsu, 2011). Additionally, functions such as emails, bulletin boards, chat rooms, forums, and online discussions can also encourage teacher-student interactions and enable learners to learn and exchange ideas and opinions freely as well as to participate in discussion activities to deepen their understanding of the topics (Chang, Chen, \& Hsu, 2011; Liu, Ho, \& Song, 2011).

According to Karakaya (2010), the introduction of internet and Computer Mediated Communication (CMC) have made L2 learning easier because these provide huge amount of input, give opportunities for interaction and finally use more authentic materials. Therefore, teachers should change their teaching methodologies, teaching aids and exercises in line with changing needs of students and technology because online learning offers a community of inquiry, social presence, cognitive presence, instructor presence and supports critical thinking with its rich resources (Anderson, 2011).

It is clear that, Facebook promises advantages, thus there is a necessity of changes in learning contexts. In this study, therefore, secondary school English teachers' perceptions about the use of Facebook in teaching Literature are investigated.

\section{METHODOLOGY}

A total of 100 questionnaires were completed in which 92 were received from female teachers and 8 were received from male teachers from secondary schools in peninsular Malaysia. The participants were school teachers who are teaching English for lower secondary school students. All the teachers chosen had Facebook account and that made the research to be conducted easily.

The design of this study is quantitative in nature in which a 5-point Likert-scale ranging as strongly disagree, disagree, uncertain, agree, strongly agree was developed based on the previous studies as a measuring instrument. The questionnaires were distributed among the teachers to elicit their perceptions about the use of Facebook and its significance in English language teaching and learning process in the context of Literature classrooms.

The researchers consulted several studies that were conducted to elicit participants' perceptions towards various dynamics of English literature teaching and learning through using questionnaires (Dehbozorgi, 2012; Soku, 2011; Karahan; 2007). The researchers designed the questionnaire and the final instrument had 30 items divided into the following six sub-categories: i). Necessity and viability of Facebook (5 items), ii). Usefulness of Facebook (8 items), iii). Willingness to learn how to use 
Facebook (3 items), iv). Willingness to use Facebook (6 items), v). Dehumanizing effects of Facebook (4 items) and vi). Practical problems (4 items).

For the analysis of the demographic data, frequency and percentages were used; whereas for the description of other items, mean scores, frequency and percentages were employed to describe the teachers' perception on the use of Facebook in teaching Literature for lower secondary school students. The data generated through the questionnaires was manually entered, coded and analyzed using SPSS program aiming to answer the research questions.

The initial version of the questionnaire, which had 30 items, was given to three senior teachers from secondary schools in Malaysia. They were requested to suggest any appropriate changes to improve the quality of the instrument. Their comments were considered and some changes have been made to the questionnaire before it was piloted. The Cronbach Alpha value for the instrument is 0.78, which is a highly acceptable consistency of reliability.

\section{FINDINGS}

The findings are presented in seven categories. First, the demographic data are presented, which is then followed by the next six categories such as necessity and viability of Facebook, usefulness of Facebook, willingness to learn how to use Facebook, willingness to use Facebook, dehumanizing effects of Facebook and practical problems.

There are 92 female (92\%) and 8 male (8\%) respondents who participated by filling in the questionnaire. There are 23 respondents (23\%) in the age group of 20-30 years, 37 respondents (37\%) in the age group of 31-40 years and 21 respondents $(21 \%)$ in the age group of 41-50 years and 19 respondents (19\%) in the age group of 51-60 years. In terms of teaching experience, all respondents have more than 5 years of teaching experience. There are 90 respondents (90\%) from urban area schools and 10 respondents $(10 \%)$ from rural area schools and all the 100 respondents are majoring in English. In addition to that, it has been confirmed that each respondents has Facebook account and 87 respondents (87\%) log on to Facebook daily, 10 respondents (10\%) log on to Facebook once a week and 3 respondents (3\%) log on once a month. Table 1 presents the summary of responses of respondents on demographic questions.

Table 1: Demographic Findings

\begin{tabular}{|c|c|c|c|c|c|}
\hline \multirow{2}{*}{ Gender } & \multicolumn{2}{|c|}{ Male } & \multicolumn{2}{|c|}{ Female } & \multirow{2}{*}{$\begin{array}{c}\text { Total } \\
100 \\
(100 \%)\end{array}$} \\
\hline & \multicolumn{2}{|c|}{$8(8 \%)$} & \multicolumn{2}{|c|}{$92(92 \%)$} & \\
\hline \multirow{2}{*}{ Age } & $20-30$ & $31-40$ & $41-50$ & $51-60$ & \multirow{2}{*}{$\begin{array}{c}\text { Total } \\
100 \\
(100 \%)\end{array}$} \\
\hline & $\begin{array}{c}23 \\
(23 \%)\end{array}$ & $\begin{array}{c}37 \\
(37 \%)\end{array}$ & $\begin{array}{c}21 \\
(21 \%)\end{array}$ & $\begin{array}{c}19 \\
(19 \%)\end{array}$ & \\
\hline
\end{tabular}




\begin{tabular}{ccccc}
\hline \multirow{2}{*}{ School } & \multicolumn{2}{c}{ Urban } & Rural & Total \\
& \multicolumn{2}{c}{$90(90 \%)$} & $10(10 \%)$ & $(100 \%)$ \\
\cline { 2 - 4 } & Daily & Once a week & Once a month & Total \\
Frequency of & & & & 100 \\
logging on to & 87 & 10 & 3 & \\
Facebook & $(87 \%)$ & $(10 \%)$ & $(3 \%)$ & \\
\hline
\end{tabular}

As seen in Table 2, 65.0\% of the teachers disagreed that their schools are not ready to use Facebook in the teaching and learning process. Almost $75.0 \%$ of the teachers found Facebook use in education is inevitable. In addition to that almost $84.0 \%$ of the teachers do not agree with the statement where Facebook is not necessary in teaching and learning. There were about $88.0 \%$ of the teachers who agreed that Facebook is useful to be used as a tool in teaching and learning of literature. Finally almost $52.0 \%$ of the teachers disagreed that their school could not afford to buy computers for all the students.

Table 2: Necessity and Viability of Facebook

\begin{tabular}{lllllll}
\hline No & \multicolumn{1}{c}{ Item } & \multicolumn{5}{c}{ Teacher response (\%) } \\
\cline { 3 - 7 } & & SD & D & U & A & SA \\
\hline 1 & $\begin{array}{l}\text { Our schools are not ready } \\
\text { to use Fb in the teaching } \\
\text { and learning process }\end{array}$ & 15.0 & 50.0 & 9.0 & 24.0 & 2.0 \\
\hline 2 & $\begin{array}{l}\text { Fb use in education is } \\
\text { inevitable }\end{array}$ & 1.0 & 18.0 & 6.0 & 64.0 & 11.0 \\
\hline 3 & $\begin{array}{l}\text { Fb use in teaching and } \\
\text { learning of literature is } \\
\text { unnecessary }\end{array}$ & 12.0 & 72.0 & 7.0 & 8.0 & 1.0 \\
\hline 4 & $\begin{array}{l}\text { Fb is a very useful teaching } \\
\text { literature tool for the school }\end{array}$ & 1.0 & 8.0 & 3.0 & 66.0 & 22.0 \\
\hline 5 & $\begin{array}{l}\text { My schools cannot afford } \\
\text { to buy computers }\end{array}$ & 9.0 & 43.0 & 22.0 & 20.0 & 6.0 \\
\hline
\end{tabular}

Table 3 presents the usefulness of Facebook in teaching Literature secondary school students. As can be seen in the table below, $68.0 \%$ of the teachers disagreed that they do not need Facebook because they found their current teaching method is effective. Almost $67.0 \%$ of the teachers agreed that Facebook can really help them lessen their workload. Almost $71.0 \%$ of the teachers agreed that Facebook makes teachers more efficient and almost $51.0 \%$ of the teachers agreed that by using Facebook, teachers will have more time to teach. $99.0 \%$ of the teachers agreed that it is useful that teachers have knowledge of Facebook. Moreover $89.0 \%$ of the teachers agreed that Facebook will add variety to the literature teaching techniques. $91.0 \%$ of the teachers agreed that literature lesson will be more interesting and enjoyable if Facebook integrated in teaching. Finally $69.0 \%$ of the teachers disagreed that Facebook is irrelevant to literature teaching. 
Table 3: Usefulness of Facebook

\begin{tabular}{clllllc}
\hline No & \multicolumn{1}{c}{ Item } & \multicolumn{5}{c}{ Teacher response (\%) } \\
\cline { 2 - 6 } & \multicolumn{1}{c}{ SD } & D & U & A & SA \\
\hline 6 & $\begin{array}{l}\text { I don't need to use Fb because } \\
\text { my teaching method now is } \\
\text { quite effective }\end{array}$ & 4.0 & 64.0 & 13.0 & 18.0 & 1.0 \\
\hline 7 & & & & & \\
\hline & $\begin{array}{l}\text { Using Fb in teaching literature } \\
\text { will lessen my workload }\end{array}$ & 0.0 & 15.0 & 18.0 & 59.0 & 8.0 \\
\hline 8 & $\begin{array}{l}\text { Fb will make teachers more } \\
\text { efficient }\end{array}$ & 1.0 & 12.0 & 16.0 & 60.0 & 11.0 \\
\hline 9 & $\begin{array}{l}\text { By using Fb teachers will have } \\
\text { more time to teach }\end{array}$ & 0.0 & 18.0 & 31.0 & 48.0 & 3.0 \\
\hline 10 & $\begin{array}{l}\text { Usefulness for teachers to have } \\
\text { knowledge of Fb }\end{array}$ & 0.0 & 1.0 & 0.0 & 62.0 & 37.0 \\
\hline 11 & $\begin{array}{l}\text { Fb will add variety to my } \\
\text { literature teaching technique }\end{array}$ & 0.0 & 2.0 & 9.0 & 70.0 & 19.0 \\
\hline 12 & $\begin{array}{l}\text { Literature lessons will be more } \\
\text { interesting and enjoyable if } \\
\text { teachers use Fb }\end{array}$ & 0.0 & 3.0 & 6.0 & 73.0 & 18.0 \\
\hline 13 & $\begin{array}{l}\text { The use of Fb is irrelevant to } \\
\text { literature teaching }\end{array}$ & 7.0 & 62.0 & 21.0 & 9.0 & 1.0 \\
\hline
\end{tabular}

As seen in Table 4, 98.0\% of the teachers agreed that they are interested in learning how to use Facebook in teaching literature. $67.0 \%$ of the teachers disagreed that learning how to use Facebook is difficult. Finally $90.0 \%$ of the teachers disagreed that they are not really interested in learning more about Facebook.

Table 4: Willingness to Learn How to Use Facebook

\begin{tabular}{clccccc}
\hline \multirow{2}{*}{ No } & \multicolumn{1}{c}{ Item } & \multicolumn{5}{c}{ Teacher response (\%) } \\
\cline { 3 - 6 } & & $\mathrm{SD}$ & $\mathrm{D}$ & $\mathrm{U}$ & $\mathrm{A}$ & $\mathrm{SA}$ \\
\hline 14 & $\begin{array}{l}\text { I am interested in learning how to } \\
\text { use Fb in teaching literature }\end{array}$ & 0.0 & 1.0 & 1.0 & 74.0 & 24.0 \\
\hline 15 & Learning how to use Fb is difficult & 7.0 & 60.0 & 19.0 & 12.0 & 2.0 \\
\hline 16 & $\begin{array}{l}\text { I am not really interested in } \\
\text { learning more about } \mathrm{Fb}\end{array}$ & 17.0 & 73.0 & 6.0 & 3.0 & 1.0 \\
\hline
\end{tabular}

Table 5 presents on the willingness to use Facebook in teaching Literature for secondary school students. $52.0 \%$ of the teachers disagreed that there is nothing motivating them to use Facebook in the literature lesson and $78.0 \%$ of the teachers disagreed that they are not willing to use Facebook in their lessons. 66.0\% disagreed that they feel helpless when they are in Facebook environment. In addition to that, $83.0 \%$ of the teachers disagreed to the statement where they afraid that they will ruin the Facebook group and its setting. $79.0 \%$ of the teachers disagreed that Facebook makes teachers feel uncomfortable and finally $60.0 \%$ of the teachers agreed that they feel confident about their ability to use Facebook. 
Table 5: Willingness to Use Facebook

\begin{tabular}{|c|l|c|c|c|c|c|}
\hline No & \multicolumn{1}{|c|}{ Item } & \multicolumn{5}{|c|}{ Teacher response (\%) } \\
\cline { 3 - 7 } & & \multicolumn{3}{|c|}{ SD } & D & A \\
\hline 17 & $\begin{array}{l}\text { There is nothing to motivate me to } \\
\text { use Fb in my literature lessons }\end{array}$ & 3.0 & 49.0 & 9.0 & 36.0 & 3.0 \\
\hline 18 & $\begin{array}{l}\text { I'm not willing to use Fb in my } \\
\text { lessons }\end{array}$ & 8.0 & 70.0 & 13.0 & 8.0 & 1.0 \\
\hline 19 & $\begin{array}{l}\text { I feel helpless when I am in a Fb } \\
\text { environment }\end{array}$ & 9.0 & 57.0 & 19.0 & 14.0 & 1.0 \\
\hline 20 & $\begin{array}{l}\text { I am afraid I will ruin the Fb and } \\
\text { its setting }\end{array}$ & 18.0 & 65.0 & 11.0 & 4.0 & 2.0 \\
\hline 21 & $\begin{array}{l}\text { Fb makes teachers feel } \\
\text { uncomfortable }\end{array}$ & 7.0 & 72.0 & 17.0 & 4.0 & 0.0 \\
\hline 22 & $\begin{array}{l}\text { I feel confident about my ability to } \\
\text { use Fb }\end{array}$ & 1.0 & 11.0 & 28.0 & 55.0 & 5.0 \\
\hline
\end{tabular}

As seen in Table 6, 69.0\% of the teachers agreed that teaching with Facebook improve teacher student interaction and $61.0 \%$ of the teachers agreed that Facebook will change the role of teachers towards good. 55.0\% of the teachers disagreed that using Facebook in teaching literature will reduce teachers influence on the literature class and finally $56.0 \%$ of the teachers agreed that they will have more control of their class when they teach literature with the aid of Facebook.

Table 6: Dehumanizing Effect of Facebook

\begin{tabular}{clccccc}
\hline \multirow{2}{*}{ No } & \multicolumn{1}{c}{ Item } & \multicolumn{5}{c}{ Teacher response (\%) } \\
\cline { 3 - 7 } & & SD & $\mathrm{D}$ & $\mathrm{U}$ & $\mathrm{A}$ & $\mathrm{SA}$ \\
\hline 23 & $\begin{array}{l}\text { Teaching with Fb will improve } \\
\text { teacher student interaction }\end{array}$ & 2.0 & 9.0 & 20.0 & 39.0 & 30.0 \\
\hline 24 & Fb will change the role of teachers & 2.0 & 22.0 & 15.0 & 57.0 & 4.0 \\
\hline 25 & $\begin{array}{l}\text { Use of Fb in teaching literature } \\
\text { will reduce my influence on my } \\
\text { literature class }\end{array}$ & 4.0 & 51.0 & 22.0 & 22.0 & 1.0 \\
\hline 26 & $\begin{array}{l}\text { I will have more control of my } \\
\text { class when I teach literature with } \\
\text { the aid of Fb }\end{array}$ & 1.0 & 14.0 & 29.0 & 52.0 & 4.0 \\
\hline
\end{tabular}

Table 7 presents the practical problems faced by teachers towards the usage of Facebook in teaching Literature. $69 \%$ of the teachers agreed that they require more time to plan literature lessons that involve using Facebook and $83 \%$ of the teachers agreed that there is not enough time to give all students sufficient access to Facebook. 
Table 7: Practical Problems

\begin{tabular}{|c|c|c|c|c|c|c|}
\hline \multirow[t]{2}{*}{ No } & \multirow[t]{2}{*}{ Item } & \multicolumn{5}{|c|}{ Teacher response (\%) } \\
\hline & & SD & $\mathrm{D}$ & $\mathrm{U}$ & A & SA \\
\hline 27 & $\begin{array}{l}\text { Teachers will require more time to plan } \\
\text { literature lessons that involve using Fb }\end{array}$ & 1.0 & 11.0 & 19.0 & 66.0 & 3.0 \\
\hline 28 & $\begin{array}{l}\text { There is not enough time to give all } \\
\text { students sufficient access to } \mathrm{Fb}\end{array}$ & 1.0 & 6.0 & 10.0 & 67.0 & $\begin{array}{c}16 . \\
0\end{array}$ \\
\hline 29 & $\begin{array}{l}\text { Fb will interrupt my normal teaching } \\
\text { routine }\end{array}$ & 3.0 & 45.0 & 29.0 & 20.0 & 3.0 \\
\hline 30 & $\begin{array}{l}\text { There are not enough computers to } \\
\text { provide all students the opportunity to } \\
\text { use them }\end{array}$ & 1.0 & 5.0 & 10.0 & 60.0 & $\begin{array}{c}24 . \\
0\end{array}$ \\
\hline
\end{tabular}

\section{DISCUSSION}

This study offers concrete insights about the usage of Facebook in teaching literature. The results indicate that high majority of teachers support Facebook integration in literature teaching classroom. There are participants with negative attitudes or are undecided but we can help the ones against the application or undecided to change their viewpoints. The frequency of indecision may seem small but the frequency of opposition should not be underestimated since it forms nearly the quarter of total frequency and in light with their responses they can be advised the ways of dealing with possible problems they might encounter in application and be given the necessary professional skills and pedagogical knowledge in their education so that they will feel competent enough to put innovative tools into practice in their future classes and better serve student needs.

With regards to the first research question, the present study indicates that participant perceptions towards the general ease of use of Facebook in literature were overall positive. Regarding the second research question, the results specify that Facebook helps teachers in improving teaching of Literature. Lastly regarding the third research questions teachers are keen to learn more on how to use Facebook in teaching and the facilities provided by schools are sufficient enough to be used in the teaching and learning of literature. The quantitative data showed a strong favorable perception of using Facebook for English literature teaching activities.

\section{CONCLUSION}

By using Facebook, teachers can make the lessons more interesting and they can even promote richer learning environments. In addition to that, teaching Literature via Facebook does not only help to improve student teacher interaction, but also helps them to achieve better results in learning literature. To motivate the students to participate in the learning of literature more, teachers should actively conduct activities in the Facebook group. Moreover teachers and students should be exposed to Facebook in their education so that they can gain knowledge and skill. 
Furthermore, by using Facebook in teaching and learning of literature, teachers will contribute to their professionalism and keep informed about the latest news and trends of educational moves. Therefore, teacher education programs need to be updated to comply with demands of the current era and help student teachers to gain the needed technology skills to effectively integrate both latest technology and appropriate teaching styles into their future literature classes.

Lastly, schools should be conscious on the usage and capability of Facebook and provide a better internet connection facility to the students and teachers to support teaching and learning of literature. Teachers too should consider several factors that might affect the teaching and learning process because students' expectations, knowledge and background might be vary. Those factors are learners' age, the language level of the students and the socio economic status of the students.

\section{REFERENCES}

Anderson-Meger, J. (2011). Critical thinking and e-learning in social work education. International Journal of Business, Humanities and Technology, 1(2), 17-27.

Chang, C. K., Chen, G. D., \& Li, L. Y. (2008). Constructing a community of practice to improve coursework activity. Computers\& Education. 50(1), 235-247.

Chang, C. K., Chen, G. D., \& Hsu, C. K. (2011). Providing adequate interactions in online discussion forums using few teaching assistants. Turkish Online Journal of Educational Technology, 10(3), 193-202.

Dehbozorgi, E. (2012). Effects of attitude towards language learning and risk-taking on EFL students" proficiency. International Journal of English Linguistics, 2(2), 41-48.

Ellison, N. B. Steinfield, C., \& Lampe, C. (2007). The benefits of Facebook "friends:" Social capital and college students' use of online social networksites. Journal of ComputerMediated Communication, 12(4). Retrieved from http://jcmc.indiana.edu/vol12/issue14/ellison.html.

Fodeman, D., \& Monroe, M. (2009). The impact of Facebook on our students. Teacher Librarian, 36(5), 36-40.

Godwin-Jones, R. (2008). Mobile computing technologies: Lighter, faster, smarter. Language Learning \& Technology, 12(3), 3-9.

Hew, K. F. (2011). Students' and teachers' use of Facebook. Computers in Human Behavior, $27(2), 662-676$.

Johnston, K.A. (2013). A guide to educating different generations in South Africa. Issues in Informing Science and Information Technology. 10, 261-273.

Karahan, F. (2007).Language attitudes of Turkish students towards the English language and its use in Turkish context. Journal of Arts and Sciences, 7, 73-87

Karakaya, K. (2010). An investigation of English language teachers' attitudes toward computer technology and their use of technology in language teaching. Unpublished master's thesis, Middle East Technical University, The Graduate School of Social Sciences, Ankara.

Kho, M. G., \& Chuah, K. M. (2012). Encouraging ESL Discourse Exchanges via Facebook: A Study on Engineering Students Centre for Language Studies. INNOCONF2012-PPR-18, 34, 44-48.

Lenhart, A., Purcell, K., Smith, A., \& Zickuhr, K. (2010). Social Media \& Mobile Internet Use among Teens and Young Adults. Millennials. Pew internet \& American life project.

Li, L. Y. \& Chen, G. D. (2009).A coursework support system for offering challenges and assistance by analyzing students' web portfolios. Educational Technology \& Society, 12 (2), 205-221. 
Liu, E. Z. F., Ho, H. C., \& Song, Y. J. (2011). Effects of an online rational emotive curriculum on primary school students' tendencies for online and real-world aggression. Turkish Online Journal of Educational Technology, 10(3), 83-93.

Mariappan, L., Abu, A. G. B., \& Omar, A. B. (2017). Facebooking for a More Lively Interaction in Literature Classroom. Creative Education, 8, 749763.https://doi.org/10.4236/ce.2017.85056.

Mazer, J., Murphy, R., \& Simonds, C. (2009). The effects of teacher self-closure via Facebook on teacher credibility. Learning, Media, and Technology, 34(2), 175-183.

Northcote, M., \& Kendle, A. (2001). Informal online networks for learning: Making use of incidental learning through recreation. Paper presented at the International Education Research Conference, December 2-6, Fremantle, Australia.

Noyes, J. S. 2015.Universal Chalcidoidea Database. World Wide Web electronic publication. http:// www.nhm.ac.uk/chalcidoids

Roth, A. (2009). Following Plato's advice: Pedagogy and technology for the Facebook generation. Journal of Philosophy and History of Education, 59, 125-128.

Sidhu, G. K. (2003). Literature in the language classroom: Seeing through the eyes of learners. Teaching of literature in ESL/EFL contexts, 88-110.

Siegle, D. (2011). Facing Facebook: A guide for nonteens. Gifted Child Today, 34(2), 14-19.

Soku, D. (2011). Studentse Attitudes towards the Study of English and French in a Private University Setting in Ghana. Journal of Education and Practice, 2(9), 19-31.

\section{AUTHORS}

Logenthini Mariappan was born in 1986 in Alor Star, Kedah. She received her B. Ed (Hons) TESL degree from Universiti Industri Selangor (UNISEL) in 2010 and Master of Education in TESL degree from Universiti Pendidikan Sultan Idris (UPSI) in 2015. In 2016 she did her $\mathrm{PhD}$ in TESL at Universiti Pendidikan Sultan Idris. Her current research interest includes teacher development, literature and education policy and change.

Abdul Ghani Abu is Associate Professor at the English Language and Literature Department, Faculty of Languages and Communication, UPSI. His research areas include learning styles, post-colonial literature, Malaysian literature in English, comparative literature, language and curriculum and pedagogical syntax.

Ainon Omar is Associate Professor at the English Language and Literature Department, Faculty of Languages and Communication, Sultan Idris Education University. Prior to joining the University, she has had 20 years of experience teaching English language in secondary schools and had assisted the Ministry of Education in the Training of Trainers programme for English language key personnels. She obtained her doctoral degree from Nova Southeastern University majoring in Instructional Leadership (TESL). Her main interests are Pedagogical literature, children's literature, materials development and language acquisition. 